\title{
A Solvent-Induced Reversal of Regioselectivity in the Suzuki Coupling of Pyrrole Esters
}

\author{
Yanan Zhang ${ }^{\mathrm{b}}$ and Scott T. Handy ${ }^{\mathrm{a}, *}$ \\ ${ }^{a}$ Department of Chemistry, Middle Tennessee State University, Murfreesboro, TN 37132, (615) 904-8114, FAX (615) \\ 898-5182. ${ }^{b}$ RTI International, Research Triangle Park, NC
}

\begin{abstract}
During a study of the regioselectivity of the Suzuki coupling of dihalopyrrole esters, the first instance of a reversal of regioselectivity based upon a change in reaction solvent has been observed. It is believed that this change in regioselectivity is due to a change in solvation of the pyrrole ester, since a change in chemical shift values is observed for the C3 and C5 protons upon going from DMF to chloroform to 3:1 benzene/methanol. An attempted application of this regioselectivity to the synthesis of the lamellarin family of natural products is reported as well.
\end{abstract}

\section{INTRODUCTION}

An ongoing focus of research in the Handy group has been the development of a one-pot polycoupling approach to substituted heteroaromatics. [1] The basic concept is to perform multiple couplings in a regiocontrolled, sequential fash-

\section{RESULTS AND DISCUSSION}

Dibromide 1 was a particularly interesting compound. Originally it had been obtained as an undesired by-product from some halogenation reactions in our synthetic studies targeting the lamellarins. [4] Since it could also be reliably

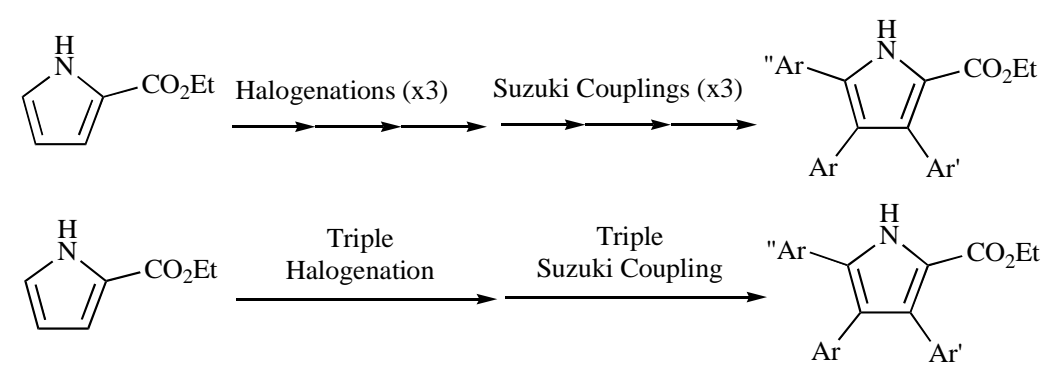

Fig. (1). The Polycoupling Concept.

ion on a polyhalo starting material. The advantages of this approach are that it maintains the flexibility and functional group tolerance inherent in modern cross-coupling reactions, but decreases the number of steps required in a strictly sequential coupling approach to only one halogenation and one coupling event (Fig. 1). [2]

One key question in this approach was being able to predict the regioselectivity in each of these coupling events. We have previously reported a predictive method that is based on the ${ }^{1} \mathrm{H}$ NMR chemical shift data for the starting, nonhalogenated heteroaromatic. [3] This method has worked very well in predicting the results of reactions reported in the literature as well as additional reactions conducted in these labs, including previous studies of the coupling of dihalopyrrole esters. [1] Most of these substrates behaved in a normal predictable fashion, with the exception of the 4-aryl-3,5dibromopyrrole esters, such as $\mathbf{1}$ (Table 1). The unexpected results from these couplings are the subject of this paper.

*Address correspondence to this author at the Department of Chemistry, Middle Tennessee State University, Murfreesboro, TN 37132, (615) 9048114, Fax: (615) 898-5182; E-mail: shandy@mtsu.edu prepared in good yield and would afford a direct regiocontrolled dicoupling route to the lamellarins that would be shorter than previous approaches, the conditions required for such a coupling were investigated. Initial efforts noted that tetrakis(triphenylphosphine)palladium(0) was the optimal catalyst and aqueous sodium carbonate was the optimal base, all using a 3:1 mixture of toluene and ethanol as the reaction solvent. Further optimization next focussed on the reaction solvent. Much to our surprise, simply changing the reaction solvent to DMF afforded modest selectivity for monocoupling product $\mathbf{3}$, the regioisomer of $\mathbf{2}$. Stunned by this observation, a number of different solvents were studied, the results of which are seen in Table 1. On the surface, it appeared that more polar solvents generally favored formation of product $\mathbf{3}$, while less polar solvents favored product $\mathbf{2}$. Curiously, attempts to perform the reaction in toluene alone failed to afford any coupling, just recovered $\mathbf{1}$. Further, making any significant comments regarding the influence of solvent polarity on the regioselectivity was made more difficult by the presence of a significant amount of water associated with the aqueous base solution. [5] 
In attempting to determine the cause of this solvent effect on regioselectivity, two main hypotheses could be envisioned. In one case, the nitrogen on the pyrrole could serve to direct insertion of the palladium to the C5 bromide. [6] This coordination would then be possible in the ethanol/toluene mixture, but be disrupted in the more polar DMF or DMSO systems due to their greater Lewis basicity.

A second option was that differential solvation of the starting material resulted in a change of the electronics of C3 and C5. This line of reasoning was supported by ${ }^{1} \mathrm{H}$ NMR studies of the non-halogenated precursor to dibromide $\mathbf{1}$ in different solvents. [7] In deuterochloroform, the chemical shift difference between these two centers is barely detectible $(0.08 \mathrm{ppm})$. On going to d6-DMSO, the $\mathrm{C} 3$ proton became clearly more electron deficient (more deshielded), with a chemical shift difference of $0.15 \mathrm{ppm}$ between it and the C5 proton. On the other hand, in a 3:1 mixture of d6-benzene and $\mathrm{d} 4$-methanol, the C5 proton became more deshielded,

Table 1. Solvent Influence on Product Ratio

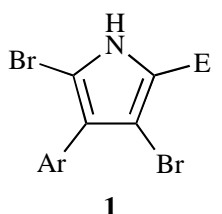

$\mathrm{Ar}=3,4-$ diMeOC $_{6} \mathrm{H}_{3}$

$\mathrm{E}=\mathrm{CO}_{2} \mathrm{Et}$

$\mathrm{Ar}^{\prime}=\mathrm{p}-\mathrm{MeOC}_{6} \mathrm{H}_{4}$

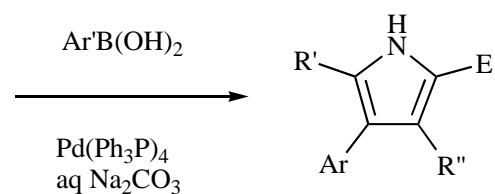

solvent, $95^{\circ} \mathrm{C}$

$2 \mathrm{R}^{\prime}=\mathrm{Ar}^{\prime}, \mathrm{R}^{\prime \prime}=\mathrm{Br}$

$3 \mathrm{R}^{\prime}=\mathrm{Br}, \mathrm{R}^{\prime \prime}=\mathrm{Ar}^{\prime}$

\begin{tabular}{|c|c|c|c|}
\hline Entry & Solvent & Yield $^{\mathbf{a}}$ & ${\text { Ratio }(\mathbf{2 : 3})^{\mathbf{b}}}$ \\
\hline \hline 1 & Toluene/Ethanol (3:1) & $29 / 70 /--$ & $1: 2$ \\
\hline 2 & Acetonitrile & $30 / 45 / 17$ & $2: 3$ \\
\hline 3 & Dioxane & $60 / 31 / 6$ & $1: 3$ \\
\hline 4 & DMF & $--/ 57 / 33$ & $1: 4$ \\
\hline 5 & DMSO & $37 / 50 / 10$ & NA \\
\hline 6 & Nitromethane & No rxn & NA \\
\hline 7 & Toluene & No rxn & \\
\hline
\end{tabular}

${ }^{a}$ Isolated yield of starting material/monocoupled product ( 2 and $\left.\mathbf{3}\right) /$ dicoupled product. ${ }^{\mathrm{b}}$ Ratio determined by ${ }^{1} \mathrm{H}$ NMR.

Table 2. Influence of Boronic Acid on Product Ratio<smiles>Fc1[nH]c(Br)c(Br)c1Br</smiles>

$\mathrm{Ar}=3,4-\mathrm{diMeOC}_{6} \mathrm{H}_{3}$ $\mathrm{E}=\mathrm{CO}_{2} \mathrm{Et}$

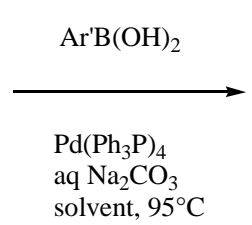

solvent, $95^{\circ} \mathrm{C}$

$2 \mathrm{R}^{\prime}=\mathrm{Ar}^{\prime}, \mathrm{R}^{\prime \prime}=\mathrm{Br}$

$3 \mathrm{R}^{\prime}=\mathrm{Br}, \mathrm{R}^{\prime \prime}=\mathrm{Ar}^{\prime}$

\begin{tabular}{|c|c|c|c|c|}
\hline Entry & Boronic Acid (Ar') & Solvent & Isolated Yield ${ }^{\text {a }}(\mathbf{\%})$ & Ratio ${ }^{\mathbf{b}}(\mathbf{2 : 3})$ \\
\hline \hline 1 & $\mathrm{pMeOC}_{6} \mathrm{H}_{4}$ & Toluene/Ethanol & 53 & $22: 1$ \\
\hline 2 & $\mathrm{pMeOC}_{6} \mathrm{H}_{4}$ & DMF & 57 & $6: 1$ \\
\hline 3 & $\mathrm{oMeOC}_{6} \mathrm{H}_{4}$ & Toluene/Ethanol & 57 & $1: 3$ \\
\hline 4 & $\mathrm{oMeOC}_{6} \mathrm{H}_{4}$ & DMF & 53 & $20: 1$ \\
\hline 5 & $\mathrm{pAcC}_{6} \mathrm{H}_{4}$ & Toluene/Ethanol & 68 & $10: 1$ \\
\hline 6 & $\mathbf{1 0}^{\mathrm{c}}$ & Toluene/Ethanol & 6 \\
\hline
\end{tabular}

${ }^{a}$ Mixture of both isomers. ${ }^{\mathrm{b}}$ Ratio determined by ${ }^{1} \mathrm{H}$ NMR. ${ }^{\mathrm{c}} \mathbf{1 0}=2$-(3',4'-dimethoxyphenyl)ethanol. 
with a wider gap of $0.25 \mathrm{ppm}$ between it and the $\mathrm{C} 3$ proton. [8].

Beyond the obvious question regarding why this solvent dependence was observed for the couplings of $\mathbf{1}$, there was also the question of how general this method would be. To that end, compound 1 was subjected to Suzuki couplings with a range of arylboronic acids, including electron rich and electron deficient ones. (Table 2) In all cases, the ethanol/toluene solvent mixture afforded good to excellent selectivity for coupling at C5, while the use of DMF as the solvent afforded modest selectivity for coupling at C3. Some reduction in $\mathrm{C} 5$ selectivity was observed with the use of an ortho-substituted boronic acid, but the corresponding loss of C3 selectivity for reactions run in DMF was not observed (entries 3 and 4).

The impact of the C4-aryl group was also examined. Electron deficient aryl groups such as 3,4-difluorophenyl or p-acetylphenyl continued to afford the same selectivity trends. (Table 3) Interestingly, very little change in the product ratio were observed for either of these new 4-aryl groups. This observation appears to indicate that the electronic influence of this 4-aryl group is surprisingly insignificant in these systems, perhaps indicating that the presence of the two bromides at C3 and C5 sterically hinder the ability of the 4aryl group and the pyrrole core to be sufficiently co-planar for overlap of the two pi systems.

With this regioselective coupling in hand, it was applied to a potential second generation synthesis of the lamellarins. Thus, dibromide $\mathbf{1}$ was coupled first with boronic acid $\mathbf{1 0}$ and then dimethoxyphenylboronic acid to afford compound 11. The plan was then to intercept compound 12, an intermediate in Steglich's synthesis of Lamellarin G trimethyl ether. [9]. (Fig. 2) Initially, this double coupling did not appear to be very promising since the second coupling failed to occur using just ethanol/toluene as the solvent. Fortunately, the addition of a co-solvent with the second boronic acid and an increase in the reaction temperature to $120{ }^{\circ} \mathrm{C}$ overcame this problem, with DMF affording 33\% and DMSO affording $36 \%$ of product 11 .

From compound 11, ring closure using the conditions reported in our initial synthesis of Lamellarin G trimethyl ether proceeded cleanly. [10] Unfortunately, hydrolysis of the ethyl ester to afford compound $\mathbf{1 2}$ failed to afford significant quantities of the acid, even under vigorous conditions. This situation can likely be overcome by using either a methyl or tert-butyl ester, both of which can be hydrolyzed under different conditions. From there, oxidative lactonization would complete the synthesis.

\section{CONCLUSIONS}

In conclusion, we have noted the first case of a solventinduced change in regioselectivity in the coupling of polyhaloheteroaromatics. This shift is likely limited to cases in which there is relatively little intrinsic electronic different between the two centers as well as Lewis acidic or basic sites since no similar reversals have been observed in our work on pyridines and 2-formylthiophene. [1] Nevertheless, there are other similarly unbiased systems and it is certainly worth bearing in mind the influence of solvent for future studies of regioselectivity in cross-coupling reactions. [11].

\section{EXPERIMENTAL}

\section{3,5-dibromo-4-(3,4-dimethoxyphenyl)-1H-pyrrole-2- carboxylic Acid Ethyl Ester (1)}

A solution of $380 \mathrm{mg}(1.38 \mathrm{mmol})$ of $4-(3,4-$ dimethoxyphenyl)-1 $H$-pyrrole-2-carboxylic acid ethyl ester in $15 \mathrm{~mL}$ of DMF was chilled to $0{ }^{\circ} \mathrm{C}$. To this solution was added $516.5 \mathrm{mg}(2.90 \mathrm{mmol})$ of NBS portionwise. The reac-

Table 3. Influence of 4-Aryl Group on Regioselectivity

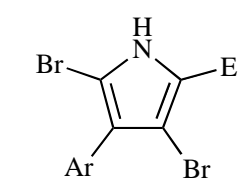

$$
\mathrm{E}=\mathrm{CO}_{2} \mathrm{Et}
$$

$4 \mathrm{Ar}=3,4-\mathrm{DiFC}_{6} \mathrm{H}_{3}$ $5 \mathrm{Ar}=\mathrm{p}-\mathrm{AcC}_{6} \mathrm{H}_{4}$
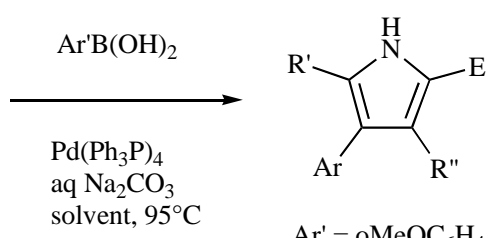

$\mathrm{Ar}^{\prime}=\mathrm{oMeOC}_{6} \mathrm{H}_{4}$

$6 \mathrm{Ar}=3,4-\mathrm{DiFC}_{6} \mathrm{H}_{3} \mathrm{R}^{\prime}=\mathrm{Ar}^{\prime}, \mathrm{R}^{\prime \prime}=\mathrm{Br}$

$7 \mathrm{Ar}=3,4-\mathrm{DiFC}_{6} \mathrm{H}_{3} \mathrm{R}^{\prime}=\mathrm{Br}, \mathrm{R}^{\prime \prime}=\mathrm{Ar}^{\prime}$

$8 \mathrm{Ar}=\mathrm{p}-\mathrm{AcC}_{6} \mathrm{H}_{4} \mathrm{R}^{\prime}=\mathrm{Ar}, \mathrm{R}^{\prime \prime}=\mathrm{Br}$

$9 \mathrm{Ar}=\mathrm{p}-\mathrm{AcC}_{6} \mathrm{H}_{4} \mathrm{R}^{\prime}=\mathrm{Br}, \mathrm{R}^{\prime \prime}=\mathrm{Ar}^{\prime}$

\begin{tabular}{|c|c|c|c|c|}
\hline Entry & Aryl Group (Ar) & Solvent & Yield $^{\mathbf{a}}$ & Ratio $^{\mathbf{b}}\left(\mathbf{6 : 7}\right.$ or 8:9) $^{-1}$ \\
\hline \hline 1 & $3,4-\mathrm{DiFC}_{6} \mathrm{H}_{3}$ & Toluene/Ethanol & $39 / 52 /-$ & $10: 1$ \\
\hline 2 & $3,4-\mathrm{DiFC}_{6} \mathrm{H}_{3}$ & DMF & $-/ 57 / 33$ & $1: 3$ \\
\hline 3 & $3,4-\mathrm{DiFC}_{6} \mathrm{H}_{3}$ & DMSO & $-/ 56 / 29$ & $8: 1$ \\
\hline 4 & $\mathrm{pAcC}_{6} \mathrm{H}_{4}$ & Toluene/Ethanol & $37 / 60 /-$ & $1: 4$ \\
\hline 5 & $\mathrm{pAcC}_{6} \mathrm{H}_{4}$ & DMSO & $-/ 46 / 42$ & \\
\hline
\end{tabular}

${ }^{\mathrm{a}}$ Isolated yield of starting material/monocoupled product $(\mathbf{6}, \mathbf{7}, \mathbf{8}$, or $\mathbf{9}) /$ dicoupled product. ${ }^{\mathrm{b}}$ Ratio determined by ${ }^{1} \mathrm{H}$ NMR. 


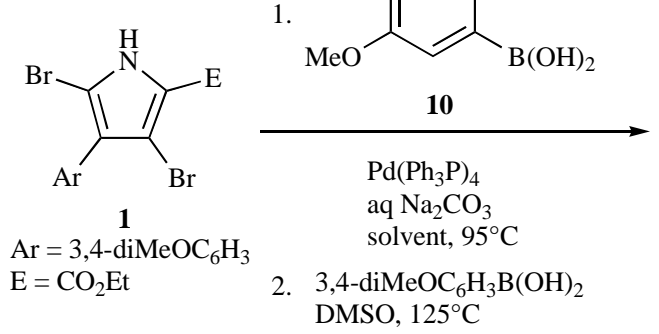<smiles>COc1cc(CCO)c(-c2[nH]c(F)c([Al])c2[Al])cc1OC</smiles>
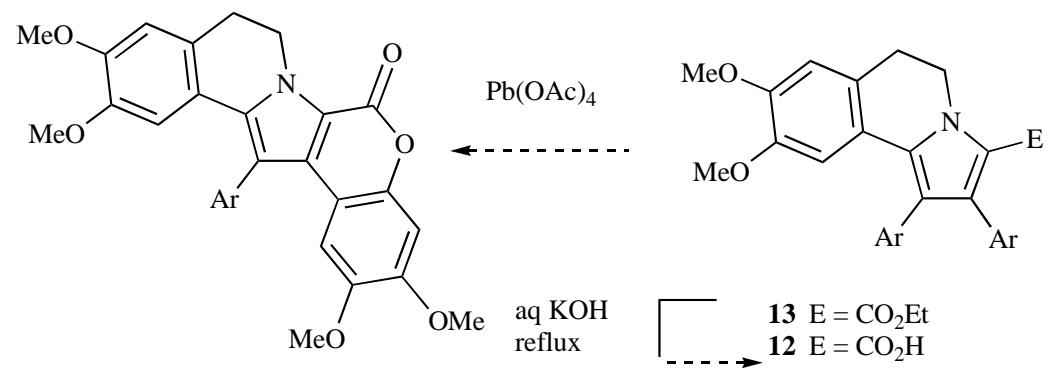

Lamellarin G trimethyl ether

Fig. (2). Potential Formal Synthesis of Lamellarin G Trimethyl Ether.

tion was allowed to warm to room temperature overnight. The reaction was quenched with $30 \mathrm{~mL}$ of water and extracted with EtOAc ( $3 \times 20 \mathrm{~mL})$. The combined organic layers were separated, washed sequentially with aqueous $\mathrm{Na}_{2} \mathrm{~S}_{2} \mathrm{O}_{3}$, water, and brine, and concentrated in vacuo to afford $494 \mathrm{mg}(83 \%)$ of 1 as a white solid. $\mathrm{Mp}=126-128^{\circ} \mathrm{C}$, ${ }^{1} \mathrm{H}$ NMR $\left(360 \mathrm{MHz}, \mathrm{CDCl}_{3}\right) \delta$ 6.97-6.92 (m, 3H), $4.42(\mathrm{q}$, $2 \mathrm{H}, \mathrm{J}=7.2), 3.91(\mathrm{~s}, 3 \mathrm{H}), 3.89(\mathrm{~s}, 3 \mathrm{H}), 1.40(\mathrm{t}, 3 \mathrm{H}, \mathrm{J}=7.2)$, pyrrole $\mathrm{NH}$ not observed; ${ }^{13} \mathrm{C} \mathrm{NMR}\left(90 \mathrm{MHz}, \mathrm{CDCl}_{3}\right) \delta$ $160.1,148.5,148.3,126.5,124.3,122.7,121.6,113.4,110.7$, 104.6, 104.0, 61.4, 55.9, 55,7, 14.3; IR (neat) 3234 (s), 2930 (m), 1679 (s), 1584 (w), 1550 (w), 1520 (w), 1479 (m), 1436 (m), 1353 (m), 1246 (s), 1138 (m), 1028 (m), 766 (w). HRMS (EI) calcd for $\mathrm{C}_{15} \mathrm{H}_{15} \mathrm{Br}_{2} \mathrm{NO}_{4}$ 430.9368, found 430.9369 .

\section{3-bromo-4-(3,4-dimethoxyphenyl)-5-(4-methoxyphenyl)- $1 H$-pyrrole-2-carboxylic Acid Ethyl Ester (2)}

To a solution of $20 \mathrm{mg}(0.046 \mathrm{mmol})$ of $1,7.7 \mathrm{mg}(0.051$ mmol) of para-methoxyphenylboronic acid, and $1.1 \mathrm{mg}$ (0.0009 mmol) of tetrakis(triphenylphosphine) palladium $(0)$ in $0.3 \mathrm{~mL}$ of toluene/ethanol (3:1) was added $0.05 \mathrm{~mL} 2 \mathrm{M}$ sodium carbonate. The reaction was stirred at $95^{\circ} \mathrm{C}$ for $30 \mathrm{~h}$. The reaction was quenched with $3 \mathrm{~mL}$ of water and extracted with EtOAc $(2 \times 5 \mathrm{~mL})$. The combined organic layers were washed with water and brine and dried with magnesium sulfate. The solvent was removed in vacuo. The resulting residue was purified on silica gel, using 1:3 EtOAc-hexanes to afford $14.9 \mathrm{mg}(70 \%)$ of $\mathbf{2}$ as a white solid, along with 5.8 mg $(29 \%)$ of unreacted 1. Mp $=133-134^{\circ} \mathrm{C},{ }^{1} \mathrm{H}$ NMR $(360$ $\left.\mathrm{MHz}, \mathrm{CDCl}_{3}\right) \delta 9.22$ (br s, $\left.1 \mathrm{H}\right), 7.16(\mathrm{~d}, 2 \mathrm{H}, \mathrm{J}=7.2$ ), 6.856.77 (m, 5H), 4.38 (q, 2H, J = 7.2), 3.94 (s, 3H), 3.77 (s, 3H), $3.76(\mathrm{~s}, 3 \mathrm{H}), 1.40(\mathrm{t}, 3 \mathrm{H}, \mathrm{J}=6.8) ;{ }^{13} \mathrm{C} \mathrm{NMR}(90 \mathrm{MHz}$, $\left.\mathrm{CDCl}_{3}\right) \delta 160.3,159.4,148.5,148.1,133.0,128.6$ (2 C's), 125.9, 124.8, 123.3, 123.0, 114.0 (2 C's), 113.8, 110.8, 106.9, 105.4, 60.7, 55.8, 55.7, 55.2, 14.4; IR (neat) 3277 (s),
2994 (m), 2835 (w), 2671 (s), 1621 (w), 1582 (w), 1557 (w), 1523 (s), 1464 (s), 1439 (m), 1418 (w), 1295 (m), 1253 (s), 1205 (m), 1138 (m), 1029 (s), 834 (w), 731 (w). HRMS (EI) calcd for $\mathrm{C}_{22} \mathrm{H}_{22} \mathrm{BrNO}_{5} 459.0681$, found 459.0679 .

\section{3-bromo-4-(3,4-dimethoxyphenyl)-5-(2-methoxyphenyl)- $1 H$-pyrrole-2-carboxylic Acid Ethyl Ester}

Following the same procedure as for compound 2, $20 \mathrm{mg}$ $(0.046 \mathrm{mmol})$ of $\mathbf{1}, 8.4 \mathrm{mg}(0.055 \mathrm{mmol})$ of 2methoxyphenylboronic acid were used. $12.0 \mathrm{mg}(57 \%)$ was obtained. ${ }^{1} \mathrm{H}$ NMR $\left(360 \mathrm{MHz}, \mathrm{CDCl}_{3}\right) \delta 10.15$ (br s, $\left.1 \mathrm{H}\right)$, 7.27-7.24 (m, 1H), $7.00(\mathrm{~d}, 1 \mathrm{H}, \mathrm{J}=1.4), 6.96(\mathrm{~d}, 1 \mathrm{H}, \mathrm{J}=$ 1.0), 6.86-6.83 (m, 2H), 6.77-6.75 (m, 2H), 4.39 (q, 2H, J = 7.6), $3.90(\mathrm{~s}, 3 \mathrm{H}), 3.88(\mathrm{~s}, 3 \mathrm{H}), 3.75(\mathrm{~s}, 3 \mathrm{H}), 1.40(\mathrm{t}, 3 \mathrm{H}) ;{ }^{13} \mathrm{C}$ NMR $\left(90 \mathrm{MHz} \mathrm{CDCl}_{3}\right) \delta 161.1,148.5,148.0,130.4,129.7$, 129.1, 126.7, 122.9, 122.6, 120.7, 113.7, 113.3, 111.2, 110.9, $110.7,106.3,105.4,60.6,55.8,55.7,55.6,14.4$; IR (neat) $3278(\mathrm{~m}), 2954(\mathrm{~m}), 2930(\mathrm{~m}), 1718$ (s), $1583(\mathrm{w}), 1522(\mathrm{w})$, 1465 (s), 1432 (w), 1251 (s), 1138 (w), 1027 (m), 765 (w). HRMS (EI) calcd for $\mathrm{C}_{22} \mathrm{H}_{22} \mathrm{BrNO}_{5}$ 459.0681, found 459.0680 .

\section{5-(4-acetylphenyl)-3-bromo-4-(3,4-dimethoxyphenyl)-1H- pyrrole-2-carboxylic Acid Ethyl Ester}

Following the same procedure as for compound 2, $20 \mathrm{mg}$ $(0.046 \mathrm{mmol})$ of $\mathbf{1}$ and $9.1 \mathrm{mg}(0.55 \mathrm{mmol})$ of $4-$ acetylphenylboronic acid were used. $11.6 \mathrm{mg}(53.2 \%)$ was obtained. ${ }^{1} \mathrm{H}$ NMR $\left(360 \mathrm{MHz}, \mathrm{CDCl}_{3}\right) \delta 9.39$ (br s, $\left.1 \mathrm{H}\right), 7.82$ $(\mathrm{d}, 2 \mathrm{H}, \mathrm{J}=8.3), 7.28(\mathrm{~d}, 2 \mathrm{H}, \mathrm{J}=8.6) 6.74-6.72(\mathrm{~m}, 2 \mathrm{H}), 6.51$ $(\mathrm{s}, 1 \mathrm{H}), 4.36(\mathrm{q}, 2 \mathrm{H}, \mathrm{J}=7.2 \mathrm{~Hz}), 3.78(\mathrm{~s}, 3 \mathrm{H}), 3.76(\mathrm{~s}, 3 \mathrm{H})$, $.6(\mathrm{~s}, 3 \mathrm{H}), 1.38(\mathrm{t}, 3 \mathrm{H}, \mathrm{J}=7.2 \mathrm{~Hz}) ;{ }^{13} \mathrm{C} \mathrm{NMR}(90 \mathrm{MHz}$, $\left.\mathrm{CDCl}_{3}\right) \delta 197.8,159.8,148.2,147.9,138.8,135.5,140.0$, 128.7, 127.5, 124.6, 122.4, 120.9, 113.4, 111.2, 110.7, 104.2, 60.7, 55.8, 55.6, 31.8, 14.0; IR (neat) $3257(\mathrm{~m}), 2925(\mathrm{~m})$, 1680 (s), 1606 (m), 1524 (w), 1403 (m), 1378 (m), 1335 (w), 1245 (s), 1181 (m), 1139 (w), 1026 (m), $859(\mathrm{w}), 765$ (w). 
HRMS (EI) calcd for $\mathrm{C}_{23} \mathrm{H}_{22} \mathrm{BrNO}_{5}$ 471.0681, found 471.0682 .

\section{3-bromo-4-(3,4-dimethoxyphenyl)-5-[2-(2-hydroxyethyl)- 4,5-dimethoxyphenyl]-1H-pyrrole-2-carboxylic Acid Ethyl Ester}

Following the same procedure as for compound $2,30 \mathrm{mg}$ $(0.069 \mathrm{mmol})$ of 1 and $39.1 \mathrm{mg}(0.173 \mathrm{mmol})$ of boronic acid 10 were used, and $25.0 \mathrm{mg}(68 \%)$ was obtained. ${ }^{1} \mathrm{H}$ NMR $\left(360 \mathrm{MHz}, \mathrm{CDCl}_{3}\right) \delta 10.93($ br s, 1H), 7.09 (s, 1H), $6.78-6.72(\mathrm{~m}, 3 \mathrm{H}), 6.64(\mathrm{~s}, 1 \mathrm{H}), 4.30(\mathrm{q}, 2 \mathrm{H}, \mathrm{J}=7.2), 3.93$ $(\mathrm{t}, 2 \mathrm{H}), 3.89(\mathrm{~s}, 3 \mathrm{H}), 3.83(\mathrm{~s}, 3 \mathrm{H}), 3.67(\mathrm{~s}, 3 \mathrm{H}), 3.55(\mathrm{~s}, 3 \mathrm{H})$, $2.80(\mathrm{t}, 2 \mathrm{H}), 1.35(\mathrm{t}, 3 \mathrm{H}) ;{ }^{13} \mathrm{C}$ NMR $\left(90 \mathrm{MHz}, \mathrm{CDCl}_{3}\right) \delta$ 161.5, 149.1, 148.4, 147.1, 147.1, 132.1, 130.2, 128.2, 124.7, 123.8, 121.6, 120.0, 114.6, 114.1, 112.2, 111.1, 110.9, 63.7, 60.3, 55.8, 55.7, 55.6, 35.0, 29.6, 14.4; IR (neat) 3439 (w, br), 3292 (w, br), $2927(\mathrm{~m}), 2850(\mathrm{w}), 1699(\mathrm{~s}), 1607(\mathrm{w})$, $1560(\mathrm{w}), 1522(\mathrm{~s}), 1466(\mathrm{~s}), 1438(\mathrm{~m}), 1381(\mathrm{w}), 1242(\mathrm{~s})$, 1208 (s), 1140 (m), 1026 (m), 860 (w), 730 (w). HRMS (EI) calcd for $\mathrm{C}_{25} \mathrm{H}_{28} \mathrm{BrNO}_{7}$ 535.1206, found 535.1205.

\section{5-bromo-4-(3,4-dimethoxyphenyl)-3-(4-methoxyphenyl)- $1 H$-pyrrole-2-carboxylic Acid Ethyl Ester (3)}

To a solution of $20 \mathrm{mg}(0.046 \mathrm{mmol})$ of $\mathbf{1}, 8.4 \mathrm{mg}(0.055$ mmol) of para-methoxyphenylboronic acid, and $2.6 \mathrm{mg}$ (0.001 mmol) of tetrakis(triphenylphosphine) palladium(0) in $0.4 \mathrm{~mL}$ of DMF was added $0.05 \mathrm{~mL} 2 \mathrm{M}$ sodium carbonate. The reaction was stirred at $95^{\circ} \mathrm{C}$ for $20 \mathrm{~h}$. The reaction was quenched with $3 \mathrm{~mL}$ of water and extracted with EtOAc $(2 \times 5 \mathrm{~mL})$. The combined organic layers were washed with water and brine and dried with magnesium sulfate. The solvent was removed in vacuo. The resulting residue was purified on silica gel, using 1:3 EtOAc-hexanes to afford 10.4 $\mathrm{mg}(53 \%)$ of $\mathbf{3}$ as a white solid. $\mathrm{Mp}=116-117^{\circ} \mathrm{C},{ }^{1} \mathrm{H}$ NMR $\left(360 \mathrm{MHz}, \mathrm{CDCl}_{3}\right) \delta 9.35(\mathrm{br} \mathrm{s}, 1 \mathrm{H}), 7.10(\mathrm{~d}, 2 \mathrm{H}, \mathrm{J}=7.2)$, 6.80-73 (m, 4H), $6.53(\mathrm{~s}, 1 \mathrm{H}), 4.21(\mathrm{q}, 2 \mathrm{H}, \mathrm{J}=7.2), 3.86(\mathrm{~s}$, $3 \mathrm{H}), 3.78(\mathrm{~s}, 3 \mathrm{H}), 3.59(\mathrm{~s}, 3 \mathrm{H}), 1.18(\mathrm{t}, 3 \mathrm{H}, \mathrm{J}=7.2) ;{ }^{13} \mathrm{C}$ NMR $\left(90 \mathrm{MHz}, \mathrm{CDCl}_{3}\right) \delta 160.2,158.6,148.0,147.6,131.8$, 122.6, 122.3, 119.9, 114.0, 113.9, 113.6, 113.4, 112.8, 110.6, 103.8, 60.4, 55.8, 55.6, 55.1, 14.0; IR (neat) 3270 (m), 2933 (w), 1669 (s), 1611 (w), 1531 (m), 1508 (w), 1464 (m), 1417 (m), 1439 (w), 1380 (w), 1245 (s), 1178 (s), 1139 (m), 1028 (m), 833 (w). HRMS (EI) calcd for $\mathrm{C}_{22} \mathrm{H}_{22} \mathrm{BrNO}_{5}$ 459.0681, found 459.0681 .

\section{5-bromo-4-(3,4-dimethoxyphenyl)-3-(2-methoxyphenyl)- $1 H$-pyrrole-2-carboxylic Acid Ethyl Ester}

Following the same procedure as for compound $3,20 \mathrm{mg}$ $(0.046 \mathrm{mmol})$ of $\mathbf{1}$ and $8.4 \mathrm{mg}(0.055 \mathrm{mmol})$ of 2 methoxyphenylboronic acid were used. $11.7 \mathrm{mg}(57 \%)$ was obtained. ${ }^{1} \mathrm{H}$ NMR $\left(360 \mathrm{MHz}, \mathrm{CDCl}_{3}\right) \delta 9.39$ (br s, $\left.1 \mathrm{H}\right), 7.23$ $(\mathrm{d}, 1 \mathrm{H}, \mathrm{J}=7.2), 7.11(\mathrm{~d}, 1 \mathrm{H}, \mathrm{J}=7.2), 6.87-6.75(\mathrm{~m}, 4 \mathrm{H})$, $6.54(\mathrm{~s}, 1 \mathrm{H}), 4.14(\mathrm{q}, 2 \mathrm{H}, \mathrm{J}=3.6), 3.82(\mathrm{~s}, 3 \mathrm{H}), 3.54(\mathrm{~s}, 3 \mathrm{H})$, $3.48(\mathrm{~s}, 3 \mathrm{H}), 1.10(\mathrm{t}, 3 \mathrm{H}, \mathrm{J}=7.2) ;{ }^{13} \mathrm{C}$ NMR $(90 \mathrm{MHz}$, $\left.\mathrm{CDCl}_{3}\right) \delta 157.1,147.8,147.4,132.2,130.4,129.7,126.7$, 125.4, 123.1, 121.4, 120.7, 113.7, 113.3, 111.2, 110.7, 110.6, 106.4, 60.2, 55.7, 55.6, 55.5, 14.0; IR (neat) 3271 (w), 2930 (m), 1774 (s), 1584 (w), 1548 (w), 1519 (w), 1467 (w), 1439 (s), $1372(\mathrm{~m}), 1310(\mathrm{~m}), 1255$ (s), 1144 (s), 1075 (m), 1027 (m), 842 (w), 764 (w). HRMS (EI) calcd for $\mathrm{C}_{22} \mathrm{H}_{22} \mathrm{BrNO}_{5}$ 459.0681, found 459.0682 .

\section{3,5-dibromo-4-(3,4-difluorophenyl)-1 $H$-pyrrole-2- carboxylic Acid Ethyl Ester (4)}

To a solution of $480 \mathrm{mg}(1.51 \mathrm{mmol})$ of 4-bromo- $1 \mathrm{H}$ pyrrole-2-carboxylic acid ethyl ester, $358 \mathrm{mg}(2.27 \mathrm{mmol})$ of 3,4 -difluorophenyl boronic acid and $87.5 \mathrm{mg}(0.07 \mathrm{mmol})$ of tetrakis(triphenylphosphine) palladium(0) in $20 \mathrm{~mL}$ of DMF was added $7.0 \mathrm{~mL}$ of $2 \mathrm{M}$ aqueous $\mathrm{Na}_{2} \mathrm{CO}_{3}$. The reaction mixture was stirred at $110^{\circ} \mathrm{C}$ for 15 hours. The reaction was quenched with $40 \mathrm{~mL}$ of water and extracted with EtOAc (3 x $30 \mathrm{~mL}$ ). The combined organic layers were washed with water and brine, and dried with anhydrous magnesium sulfate. The solvent was removed in vacuo. The resulting residue was chromatographed on silica gel, using 1:3 EtOAchexanes, to afford $246.0 \mathrm{mg}(65 \%)$ of the coupled product as a white solid. ${ }^{1} \mathrm{H}$ NMR $\left(360 \mathrm{MHz}, \mathrm{CDCl}_{3}\right) \delta 9.25(\mathrm{br} \mathrm{s}, 1 \mathrm{H})$, 7.20-7.10 (m, 5H), 4.33 (q, 2H, J = 7.2), 1.37 (t, 3H, J = 7.2); ${ }^{13} \mathrm{C}$ NMR $\left(90 \mathrm{MHz}, \mathrm{CDCl}_{3}\right) \delta 161.1,151.9,150.3,148.9$, 147.5, 131.8, 124.8, 123.9, 121.0, 119.4, 117.4, 114.0, 112.2, 60.3, 14.3; IR (neat) 3265 (s), $2921(\mathrm{w}), 1679$ (s), $1601(\mathrm{w})$, $1572(\mathrm{w}), 1523(\mathrm{w}), 1488(\mathrm{w}), 1384(\mathrm{~m}), 1297(\mathrm{~m}), 1195(\mathrm{~s})$, 1147 (m), 769 (w).

A solution of $240 \mathrm{mg}(0.956 \mathrm{mmol})$ of the above compound in $25 \mathrm{~mL}$ of DMF was chilled to $0{ }^{\circ} \mathrm{C}$. To this solution was added portionwise $349 \mathrm{mg}(1.96 \mathrm{mmol})$ of NBS. The reaction was allowed to warm to room temperature overnight. The reaction was quenched with $40 \mathrm{~mL}$ of water and extracted with EtOAc $(3 \times 30 \mathrm{~mL})$. The combined organic layers were separated and washed sequentially with saturated aqueous $\mathrm{Na}_{2} \mathrm{~S}_{2} \mathrm{O}_{3}$, water and brine, and concentrated in vacuo to afford $342 \mathrm{mg}(88 \%)$ of $\mathbf{4}$ as a white solid. $\mathrm{Mp}=$ $125-128^{\circ} \mathrm{C},{ }^{1} \mathrm{H}$ NMR $\left(360 \mathrm{MHz}, \mathrm{CDCl}_{3}\right) \delta 9.57$ (br s, $\left.1 \mathrm{H}\right)$, $7.25-7.13(\mathrm{~m}, 3 \mathrm{H}), 4.39(\mathrm{q}, 2 \mathrm{H}, \mathrm{J}=7.2), 1.39(\mathrm{t}, 3 \mathrm{H}, \mathrm{J}=$ 6.0); ${ }^{13} \mathrm{C}$ NMR $\left(90 \mathrm{MHz}, \mathrm{CDCl}_{3}\right) \delta 159.1,151.3,148.6$, $128.2,126.5,121.9,119.2\left(\mathrm{~d}, \mathrm{~J}^{\mathrm{CF}}=68.4 \mathrm{~Hz}\right), 117.0\left(\mathrm{~d}, \mathrm{~J}^{\mathrm{CF}}=\right.$ $68.4 \mathrm{~Hz}), 115.0,104.1,103.7,60.3,14.0$; IR (neat) $3232(\mathrm{~m})$, 1913 (w), 1676 (s), 1598 (m), $1544(\mathrm{w}), 1515(\mathrm{w}), 1472(\mathrm{w})$, $1437(\mathrm{~m}), 1382(\mathrm{~m}), 1264(\mathrm{~s}), 1237(\mathrm{~m}), 1191(\mathrm{~m}), 1116(\mathrm{w})$, $872(\mathrm{~m}), 816(\mathrm{~m})$. HRMS (EI) calcd for $\mathrm{C}_{13} \mathrm{H}_{9} \mathrm{Br}_{2} \mathrm{~F}_{2} \mathrm{NO}_{2}$ 392.8937, found 392.8938 .

\section{3-bromo-4-(3,4-difluorophenyl)-5-(2-methoxyphenyl)- $1 H$-pyrrole-2-carboxylic Acid Ethyl Ester (6)}

To a solution of $20 \mathrm{mg}(0.049 \mathrm{mmol})$ of $4,8.9 \mathrm{mg}(0.059$ $\mathrm{mmol})$ of 2-methoxyphenylboronic acid, and $2.8 \mathrm{mg}(0.025$ $\mathrm{mmol}$ ) of tetrakis(triphenylphosphine) palladium(0) in 0.4 $\mathrm{mL}$ of toluene-ethanol $(3: 1)$ was added $0.1 \mathrm{~mL}$ of $2 \mathrm{M}$ aqueous $\mathrm{Na}_{2} \mathrm{CO}_{3}$. The reaction mixture was stirred at $95^{\circ} \mathrm{C}$ for 15 hours. The reaction was quenched with $5 \mathrm{~mL}$ of water and extracted with EtOAc $(3 \times 5 \mathrm{~mL})$. The combined organic layers were washed with water and brine, and dried with anhydrous magnesium sulfate. The solvent was removed in vасио. The resulting residue was purified on silica gel, using 1:4 EtOAc-hexanes, to afford $11.2 \mathrm{mg}(52.0 \%)$ of $\mathbf{6}$ as a white solid. $\mathrm{Mp}=131-132^{\circ} \mathrm{C},{ }^{1} \mathrm{H}$ NMR $\left(360 \mathrm{MHz}, \mathrm{CDCl}_{3}\right) \delta$ 10.02 (br s, 1H), 7.25-7.22 (m, 1H), 7.17-7.11 (m, 2H), 6.95$6.93(\mathrm{~m}, 3 \mathrm{H}), 6.77-6.76(\mathrm{~m}, 1 \mathrm{H}), 4.38(\mathrm{q}, 2 \mathrm{H}, \mathrm{J}=7.2), 3.84$ $(\mathrm{s}, 3 \mathrm{H}), 1.40(\mathrm{t}, 3 \mathrm{H}, \mathrm{J}=3.6) ;{ }^{13} \mathrm{C}$ NMR $\left(90 \mathrm{MHz}, \mathrm{CDCl}_{3}\right) \delta$ $160.1,156.4,151.0,130.4,130.1,129.7,126.8,126.8,126.7$, $123.5,120.8,119.4\left(\mathrm{~d}, \mathrm{~J}^{\mathrm{CF}}=68.4\right), 118.4,117.1\left(\mathrm{~d}, \mathrm{~J}^{\mathrm{CF}}=\right.$ 
68.4), 111.4, 110.5, 104.8, 60.8, 55.5, 14.4; IR (neat) 3256 (w), $2924(\mathrm{~m}), 1670(\mathrm{~s}), 1603(\mathrm{w}), 1559(\mathrm{~m}), 1506(\mathrm{~m}), 1463$ (s), 1403 (m), 1251 (s), 1216 (w), 1039 (w), 772 (w), 754 (w). HRMS (EI) calcd for $\mathrm{C}_{20} \mathrm{H}_{16} \mathrm{BrF}_{2} \mathrm{NO}_{3}$ 435.0281, found 435.0279 .

\section{5-bromo-4-(3,4-difluorophenyl)-3-(2-methoxyphenyl)- $1 H$-pyrrole-2-carboxylic Acid Ethyl Ester (7)}

To a solution of $20 \mathrm{mg}(0.046 \mathrm{mmol})$ of $4,8.4 \mathrm{mg}(0.055$ $\mathrm{mmol})$ of 2-methoxyphenylboronic acid, and $2.6 \mathrm{mg}(0.0011$ $\mathrm{mmol}$ ) of tetrakis(triphenylphosphine) palladium(0) in 0.4 $\mathrm{mL}$ of DMF was added $0.05 \mathrm{~mL} 2 \mathrm{M}$ sodium carbonate. The reaction was stirred at $95^{\circ} \mathrm{C}$ for $15 \mathrm{~h}$. The reaction was quenched with $3 \mathrm{~mL}$ of water and extracted with EtOA ( $2 \mathrm{x}$ $5 \mathrm{~mL}$ ). The combined organic layers were washed with water and brine and dried with magnesium sulfate. The solvent was removed in vacuo. The resulting residue was purified on silica gel, using 1:3 EtOAc-hexanes to afford $12.0 \mathrm{mg}(57 \%)$ of 7 as a white solid. $\mathrm{Mp}=141-143^{\circ} \mathrm{C},{ }^{1} \mathrm{H}$ NMR $(360 \mathrm{MHz}$, $\left.\mathrm{CDCl}_{3}\right) \delta 9.52(\mathrm{br} \mathrm{s}, 1 \mathrm{H}), 7.25-6.80(\mathrm{~m}, 7 \mathrm{H}), 4.14(\mathrm{q}, 2 \mathrm{H}, \mathrm{J}=$ 7.2), $3.51(\mathrm{~s}, 3 \mathrm{H}), 1.10(\mathrm{t}, 3 \mathrm{H}, \mathrm{J}=3.6) ;{ }^{13} \mathrm{C} \mathrm{NMR}(90 \mathrm{MHz}$, $\left.\mathrm{CDCl}_{3}\right) \delta 160.2,156.9,132.1,130.4,129.7,129.6,125.5$, $122.1,120.8,120.0,119.3,118.1\left(\mathrm{~d}, \mathrm{~J}^{\mathrm{CF}}=68.4\right), 117.2$, $116.5\left(\mathrm{~d}, \mathrm{~J}^{\mathrm{CF}}=68.4\right), 111.4,110.5,103.7,60.4,55.0,14.0$; IR (neat) 3247 (m), 2925 (m), 1671 (s), 1603 (w), $1533(\mathrm{w})$, 1464 (s), 1406 (m), 1382 (m), 1251 (s), 1177 (w), 1117 (w), 1027 (m), 874 (w), 753 (w). HRMS (EI) calcd for $\mathrm{C}_{20} \mathrm{H}_{16} \mathrm{BrF}_{2} \mathrm{NO}_{3}$ 435.0281, found 435.0281.

\section{DMSO CONDITIONS}

Using the same conditions outlined above, but with 20 $\mathrm{mg}(0.049 \mathrm{mmol})$ of 4 and DMSO in place of DMF, $11.7 \mathrm{mg}$ $(55.3 \%)$ of 7 was obtained.

\section{4-acetylphenyl-3,5-dibromo-1H-pyrrole-2-carboxylic Acid Ethyl Ester (5)}

To a solution of $250 \mathrm{mg}(0.79 \mathrm{mmol})$ of 4-bromo- $1 \mathrm{H}$ pyrrole-2-carboxylic acid ethyl ester, $194 \mathrm{mg}(1.18 \mathrm{mmol})$ of 4 -acetylphenylboronic acid and $45.6 \mathrm{mg}(0.07 \mathrm{mmol})$ of tetrakis(triphenylphosphine) palladium(0) in $10 \mathrm{~mL}$ of DMF was added $4.0 \mathrm{~mL}$ of $2 \mathrm{M}$ aqueous $\mathrm{Na}_{2} \mathrm{CO}_{3}$. The reaction mixture was stirred at $110^{\circ} \mathrm{C}$ for 16 hours. The reaction was quenched with $20 \mathrm{~mL}$ of water and extracted with EtOAc (3 x $20 \mathrm{~mL}$ ). The combined organic layers were washed with water and brine, and dried with anhydrous magnesium sulfate. The solvent was removed in vacuo. The resulting residue was chromatographed on silica gel, using 1:3 EtOAchexanes, to afford $145.0 \mathrm{mg}$ (72\%) of the coupling product as a white solid. ${ }^{1} \mathrm{H}$ NMR $\left(360 \mathrm{MHz}, \mathrm{CDCl}_{3}\right) \delta 9.92(\mathrm{br} \mathrm{s}$, $1 \mathrm{H}), 7.92(\mathrm{~d}, 2 \mathrm{H}, \mathrm{J}=7.2), 7.57(\mathrm{~d}, 2 \mathrm{H}, \mathrm{J}=7.2), 7.33(\mathrm{~s}, 1 \mathrm{H})$, $7.23(\mathrm{~s}, 1 \mathrm{H}), 4.33(\mathrm{q}, 2 \mathrm{H}, \mathrm{J}=7.2), 2.57(\mathrm{~s}, 3 \mathrm{H}), 1.23(\mathrm{t}, 3 \mathrm{H}, \mathrm{J}$ $=7.2) ;{ }^{13} \mathrm{C}$ NMR $\left(90 \mathrm{MHz}, \mathrm{CDCl}_{3}\right) \delta 197.8,161.1,139.4$, 134.6, 129.0, 125.3, 124.8, 124.0, 120.6, 112.5, 60.6, 26.4, 14.3; IR (neat) 3306 (m), 2926 (w), 1701 (s), 1678 (s), 1604 (s), 1577 (w), 1446 (w), 1379 (m), 1266 (s), 1211 (m), 1136 (m), $926(\mathrm{w})$.

$136 \mathrm{mg}(0.53 \mathrm{mmol})$ of the above product in $20 \mathrm{~mL}$ of DMF was chilled to $0^{\circ} \mathrm{C}$. To this solution was added portionwise $193 \mathrm{mg}(1.08 \mathrm{mmol})$ of NBS. The reaction was allowed to warm to room temperature overnight. The reaction was quenched with $20 \mathrm{~mL}$ of water and extracted with
EtOAc $(3 \times 20 \mathrm{~mL})$. The combined organic layers were separated and washed sequentially with saturated aqueous $\mathrm{Na}_{2} \mathrm{~S}_{2} \mathrm{O}_{3}$, water and brine, and concentrated in vacuo to afford $180 \mathrm{mg}(82.0 \%)$ of 5 as a white solid. $\mathrm{Mp}=116-118^{\circ} \mathrm{C}$, ${ }^{1} \mathrm{H}$ NMR $\left(360 \mathrm{MHz}, \mathrm{CDCl}_{3}\right) \delta 9.85(\mathrm{br} \mathrm{s}, 1 \mathrm{H}), 8.03(\mathrm{~d}, 2 \mathrm{H}, \mathrm{J}$ $=6.5), 7.54(\mathrm{~d}, 2 \mathrm{H}, \mathrm{J}=8.3), 4.41(\mathrm{q}, 2 \mathrm{H}, \mathrm{J}=6.8), 2.64(\mathrm{~s}$, $3 \mathrm{H}), 1.41(\mathrm{t}, 3 \mathrm{H}, \mathrm{J}=7.2) ;{ }^{13} \mathrm{C}$ NMR $\left(90 \mathrm{MHz}, \mathrm{CDCl}_{3}\right) \delta$ 197.7, 159.5, 136.7, 136.1, 130.3 (2 C's), 128.2 (2 C's), 125.7, 122.1, 104.5, 103.6, 61.4, 29.6, 14.3; IR (neat) 3222 (s), 2990 (w), 1672 (s), 1603 (m), 1559 (w), 1517 (w), 1440 (w), 1413 (w), 1381 (w), 1258 (s), 1204 (m), 1012 (w), 954 (w), $840(\mathrm{w}), 756$ (w). HRMS (EI) calcd for $\mathrm{C}_{15} \mathrm{H}_{13} \mathrm{Br}_{2} \mathrm{NO}_{3}$ 412.9262 , found 412.9263 .

\section{4-acetylphenyl-3-bromo-5-(2-methoxyphenyl)- $1 \mathrm{H}$ - pyrrole-2-carboxylic Acid Ethyl Ester (8)}

To a solution of $20 \mathrm{mg}(0.048 \mathrm{mmol})$ of $\mathbf{5}, 8.8 \mathrm{mg}(0.058$ $\mathrm{mmol})$ of 2-methoxyphenylboronic acid, and $2.8 \mathrm{mg}(0.003$ $\mathrm{mmol}$ ) of tetrakis(triphenylphosphine) palladium(0) in 0.5 $\mathrm{mL}$ of toluene/ethanol (3:1) was added $0.1 \mathrm{~mL} 2 \mathrm{M}$ sodium carbonate. The reaction was stirred at $95^{\circ} \mathrm{C}$ for $15 \mathrm{~h}$. The reaction was quenched with $5 \mathrm{~mL}$ of water and extracted with EtOAc $(2 \times 5 \mathrm{~mL})$. The combined organic layers were washed with water and brine, and then dried with magnesium sulfate. The solvent was removed in vacuo. The resulting residue was purified on silica gel, using 1:4 EtOAchexanes to afford $12.7 \mathrm{mg}(60 \%)$ of $\mathbf{8}$ as a white solid. $\mathrm{Mp}=$ $122-123^{\circ} \mathrm{C},{ }^{1} \mathrm{H}$ NMR $\left(360 \mathrm{MHz}, \mathrm{CDCl}_{3}\right) \delta 10.03$ (br s, $1 \mathrm{H}$ ), $7.93(\mathrm{~d}, 2 \mathrm{H}, 7.2), 7.38(\mathrm{~d}, 2 \mathrm{H}, \mathrm{J}=7.2), 7.27-7.23(\mathrm{~m}, 2 \mathrm{H})$, 6.96-6.93 (m, 1H), 6.74-6.73 (m, 1H), $4.41(\mathrm{q}, 2 \mathrm{H}, \mathrm{J}=6.8)$, $3.82(\mathrm{~s}, 3 \mathrm{H}), 2.62(\mathrm{~s}, 3 \mathrm{H}), 1.42(\mathrm{t}, 3 \mathrm{H}, \mathrm{J}=7.2) ;{ }^{13} \mathrm{C} \mathrm{NMR}(90$ $\left.\mathrm{MHz}, \mathrm{CDCl}_{3}\right) \delta 197.9,160.1,139.5,135.6,130.7,130.6$, 130.3, 130.2, 129.7, 129.2, 128.3, 128.1, 127.8, 120.7, 111.4, 108.3, 60.8, 55.5, 26.6, 14.4; IR (neat) 3260 (w), $2924(\mathrm{~m})$, $1679(\mathrm{~s}), 1605(\mathrm{~m}), 1505(\mathrm{w}), 1474(\mathrm{~m}), 1400(\mathrm{w}), 1264(\mathrm{~s})$, $1182(\mathrm{~m}), 1040(\mathrm{~m}), 955(\mathrm{~m}), 757(\mathrm{w})$. HRMS (EI) calcd for $\mathrm{C}_{22} \mathrm{H}_{20} \mathrm{BrNO}_{4} 441.0576$, found 441.0578 .

\section{4-acetylphenyl-5-bromo-3-(2-methoxyphenyl)-1H- pyrrole-2-carboxylic Acid Ethyl Ester (9)}

To a solution of $20 \mathrm{mg}(0.048 \mathrm{mmol})$ of $\mathbf{5}, 8.8 \mathrm{mg}(0.058$ $\mathrm{mmol})$ of 2-methoxyphenylboronic acid, and $2.6 \mathrm{mg}(0.0011$ $\mathrm{mmol}$ ) of tetrakis(triphenylphosphine) palladium(0) in 0.4 $\mathrm{mL}$ of DMSO was added $0.05 \mathrm{~mL} 2 \mathrm{M}$ sodium carbonate. The reaction was stirred at $95^{\circ} \mathrm{C}$ for $10 \mathrm{~h}$. The reaction was quenched with $3 \mathrm{~mL}$ of water and extracted with EtOAc $(2 \mathrm{x}$ $5 \mathrm{~mL}$ ). The combined organic layers were washed with water and brine and dried with magnesium sulfate. The solvent was removed in vacuo. The resulting residue was purified on silica gel, using 1:4 EtOAc-hexanes to afford $9.9 \mathrm{mg}(47 \%)$ of 9 as a white solid. $\mathrm{Mp}=137-138^{\circ} \mathrm{C},{ }^{1} \mathrm{H}$ NMR $(360 \mathrm{MHz}$, $\left.\mathrm{CDCl}_{3}\right) \delta 9.32(\mathrm{br} \mathrm{s}, 1 \mathrm{H}), 7.79(\mathrm{~d}, 2 \mathrm{H}, \mathrm{J}=6.8), 2.24(\mathrm{~d}, 2 \mathrm{H}, \mathrm{J}$ $=6.8), 6.88(\mathrm{~m}, 2 \mathrm{H}), 6.76(\mathrm{~m}, 2 \mathrm{H}), 4.14(\mathrm{q}, 2 \mathrm{H}, \mathrm{J}=7.1), 3.43$ $(\mathrm{s}, 3 \mathrm{H}), 2.54(\mathrm{~s}, 3 \mathrm{H}), 1.38(\mathrm{t}, 3 \mathrm{H}, \mathrm{J}=7.1 \mathrm{~Hz}) ;{ }^{13} \mathrm{C}$ NMR $(90$ $\left.\mathrm{MHz}, \mathrm{CDCl}_{3}\right) \delta 199.5,159.8,156.6,135.0,132.2,130.7$, 129.7, 129.2, 129.1, 128.3, 127.8, 125.7, 120.0, 111.4, 110.6, 105.8, 60.4, 55.0, 29.3, 14.1; IR (neat) 3246 (m), 2923 (m), $1671(\mathrm{~s}), 1605(\mathrm{~m}), 1495(\mathrm{w}), 1465(\mathrm{~m}), 1397(\mathrm{~m}), 1380(\mathrm{~m})$, $1354(\mathrm{w}), 1249(\mathrm{~s}), 1180(\mathrm{w}), 1099(\mathrm{w}), 1026(\mathrm{w}), 953(\mathrm{w})$, 835 (w), 754 (w). HRMS (EI) calcd for $\mathrm{C}_{22} \mathrm{H}_{20} \mathrm{BrNO}_{4}$ 441.0576 , found 441.0576 . 


\section{3,4-Bis-(3,4-dimethoxyphenyl)-5-[2-(2-hydroxyethyl)-4,5- dimethoxyphenyl]-1H-pyrrole-2-carboxylic Acid Ethyl Ester (11)}

To a solution of $20 \mathrm{mg}(0.046 \mathrm{mmol})$ of $\mathbf{1}, 26.1 \mathrm{mg}$ $(0.115 \mathrm{mmol})$ of $\mathbf{1 0}$, and $2.7 \mathrm{mg}(0.0023 \mathrm{mmol})$ of $\mathrm{Pd}\left(\mathrm{PPh}_{3}\right)_{4}$ in $0.6 \mathrm{~mL}$ of toluene-ethanol (3:1), was added $0.2 \mathrm{~mL}$ of $2 \mathrm{M}$ sodium carbonate. The reaction was stirred under argon at $95^{\circ} \mathrm{C}$ for $25 \mathrm{~h}$. To the reaction was added $12.6 \mathrm{mg}(0.069$ mmol) of 3,4-dimethoxyphenylboronic acid, and $0.5 \mathrm{~mL}$ of DMSO. The reaction was stirred at $120^{\circ} \mathrm{C}$ for $20 \mathrm{~h}$. To the reaction was added $5 \mathrm{~mL}$ of water and extracted with EtOAc $(3 \times 5 \mathrm{~mL})$. The combined organic layers were washed with water and brine, and dried with magnesium sulfate. The solvent was removed in vacuo. The resulting residue was chromatographed on silica gel, using 3:1 EtOAc-hexanes, to afford $9.8 \mathrm{mg}(36 \%)$ of $\mathbf{1 1}$ as a solid. $\mathrm{Mp}=111-113^{\circ} \mathrm{C},{ }^{1} \mathrm{H}$ NMR $\left(360 \mathrm{MHz}, \mathrm{CDCl}_{3}\right) \delta 11.12(\mathrm{br} \mathrm{s}, 1 \mathrm{H}), 6.82-6.76(\mathrm{~m}$, $3 \mathrm{H}), 6.57(\mathrm{~d}, 1 \mathrm{H}, \mathrm{J}=7.2), 6.49(\mathrm{~s}, 1 \mathrm{H}), 6.43-6.39(\mathrm{~m}, 2 \mathrm{H})$, 4.19 (q, 2H, J = 7.2), $4.02(\mathrm{t}, 2 \mathrm{H}, \mathrm{J}=6.8 \mathrm{~Hz}), 3.88(\mathrm{~s}, 3 \mathrm{H})$, $3.85(\mathrm{~s}, 3 \mathrm{H}), 3.76(\mathrm{~s}, 3 \mathrm{H}), 3.68(\mathrm{~s}, 3 \mathrm{H}), 3.43(\mathrm{~s}, 3 \mathrm{H}), 3.41(\mathrm{~s}$, $3 \mathrm{H}), 2.89(\mathrm{t}, 2 \mathrm{H}, \mathrm{J}=6.8 \mathrm{~Hz}), 1.23(\mathrm{t}, 3 \mathrm{H}, \mathrm{J}=7.2 \mathrm{~Hz}) ;{ }^{13} \mathrm{C}$ NMR $\left(90 \mathrm{MHz}, \mathrm{CDCl}_{3}\right) \delta 161.5,148.9,148.1,147.6,146.8$, $136.7,133.2,132.0,130.0,129.9,127.3,127.2,125.8,125.3$ 124.6, 123.4, 122.9, 114.5, 114.0, 111.9, 110.5, 110.1, 106.1, 64.0, 59.9, 55.8, 55.7, 55.6, 55.5, 55.4, 34.9, 29.6, 14.2; IR (neat) $3530(\mathrm{w}), 3233(\mathrm{w}), 2929(\mathrm{~m}), 1685(\mathrm{~s}), 1607(\mathrm{w})$, 1557 (w), 1521 (s), 1464 (w), 1464 (m), 1434 (m), $1380(\mathrm{~m})$, 1243 (s), 1138 (m), 1115 (m), 1027 (s), 861 (w), $730(\mathrm{w})$. HRMS (EI) calcd for $\mathrm{C}_{33} \mathrm{H}_{37} \mathrm{NO}_{9} 591.2468$, found 591.2469.

\section{ACKNOWLEDGEMENT}

Generous financial support by the NIH (GM074662-01) is gratefully acknowledged as is NMR assistance by Dr. Jurgen Schulte.

\section{REFERENCES}

[1] S.T. Handy and J.J. Sabatini, Org. Lett., 2006, 8, 1537. S.T. Handy and Y. Zhang, Synthesis, 2006, 3883. S.T. Handy, T. Wilson, and A. Muth, J. Org. Chem., 2007, 72, 8496. S.T. Handy and D. Mayi, Tetrahedron Lett., 2007, 48, 8108 .

[2] G.W. Gribble and J.J Li, "Palladium in Heterocyclic Chemistry" Elssevier: London, 2006.

[3] S.T. Handy and Y. Zhang, Chem. Commun., 2006, 299.

[4] S.T. Handy, Y. Zhang, and H. Bregman, J. Org. Chem., 2004, 69, 2362.

[5] It should be noted that reactions in the absence of water failed to afford any coupling products and only resulted in recovery of starting material.

[6] For examples of chelation-driven regioselectivity, see: F. Kakiuchi and S. Murai, Activation of $\mathrm{C}-\mathrm{H}$ Bonds: Catalytic Reactions In "Activation of Unreactive Bonds and Organic Synthesis," S. Murai, Ed. Springer: Berlin, 1999.

[7] A combination of HMBC and HMQC spectroscopy was employed to determine the signals corresponding to the $\mathrm{C} 3$ and $\mathrm{C} 5$ protons.

[8] The coupling of $\mathbf{1}$ in a 3:1 mixture of benzene and methanol afforded selectivity results indistinguishable from that of the toluene/ethanol mixture.

[9] A. Heim, A. Terpin, W. Steglich, Angew. Chem. Int. Ed. Engl., 1997, 36, 155 .

[10] S.T. Handy and Y. Zhang, Org. Prep. \& Proc. Int. 2005, 37, 411.

[11] One possible application is thiophenes. K.O. Jeon, J.S. Yu, and C.K. Lee, Heterocycles 2003, 60, 2685. However, preliminary experiments have not demonstrated any solvent effect on the regioselectivity in coupling of 2,3-dibromothiophene or 2,4dibromothiophene. These experiments will be reported in due course. 